\title{
Enzyme-Sugar Relationships in Immature Sugarcane Treated With Ascorbic Acid, Cysteine, Hydrox- ylamine, Cyanide, Silicon, and Iron
}

\author{
Alex G. Alexander ${ }^{1}$
}

\section{INTRODUCTION}

The behavior of cane oxidases and certain hydrolytic enzymes is greatly modified by in vitro exposure to chemical additives $(8,9,1,2,3) .{ }^{2}$ Much work has been done at this Station to determine whether such in vitro responses of basic catalysts can be duplicated in living plants $(4,5,6)$. The most recent investigations are summarized in this paper.

Among chemicals studied were ascorbic acid, cysteine, hydroxylamine, and cyanide. Each of these is an effective oxidase inhibitor in the test tube. Silicon was included primarily to reaffirm its invertase- and oxidaseinhibitory roles (18). Application of these materials to the living cane was accomplished both as foliar sprays and nutrient-solution supplements.

\section{MATERIALS AND METHODS}

All plants were grown in the greenhouse using a sand-culture technique with controlled nutrient supply. One-eye cuttings were planted in glazed, 2 -gallon pots containing quartz sand ("silica shot"). The sand was previously treated for 12 hours with $0.01 \mathrm{~N} \mathrm{HCl}$, and thoroughly leached with tapwater. Seedlings were watered daily until 3 weeks of age. Nutrient solutions were then applied and these were continued daily until harvest at about 12 weeks. $^{3}$

Two groups of uniform plants were selected for treatment. The first set received silicon $(\mathrm{Si})$ and cyanide $(\mathrm{CN})$ as supplements to the nutrient solution, each at rates of 20 and 200 p.p.m. Iron ( $\mathrm{Fe}$ ) was provided at rates of 10 and 100 p.p.m. Additive sources were A.C.S.-grade sodium silicate, ferrous ammonium sulfate, and potassium cyanide. Control plants continued to receive the standard nutrient solution.

The second group was treated with foliar sprays at 11 weeks. Ascorbic acid, cysteine, hydroxylamine, and cyanide were applien by a Hudson

${ }^{1}$ Associate Plant Physiologist, Agricultural Experiment Station, University of Puerto Rico, Río Piedras, P.R.

${ }^{2}$ Italic numbers in parentheses refer to Literature Cited, pp. 53-4.

${ }^{3}$ Nutrient concentrations, expressed as milliequivalents per liter, were provided as follows: Nitrate, 10; phosphate, 6; potassium, 5; calcium, 3; magnesium, 2; and sulfate, 2. Microelements, expressed as parts per million, were supplied as follows: Boron, 0.05; copper, 0.02; manganese, 0.50; zinc, 0.05; molybdenum, 0.01; and iron, 1.0 . 
hand-sprayer with the nozzle adjusted for a fine-mist pattern. Tween-20 was added to facilitate coverage of all above-sand areas. Control plants received water plus Tween-20. Each experiment consisted of four replicates distributed within a randomized block design.

Plants receiving foliar sprays were harvested twice; once just prior to treatment, and again 3 days later. Only one harvest was made for the nutrition-supplement study. Both leaf and meristem samples were taken from four uniform plants of each replicate. These were frozen, lyophilized, extracted, and prepared for sugar and enzyme assay in accordance with procedures described earlier $(5,6)$.

Hydrolytic and oxidative enzymes were assayed during the present study. Phosphatase activity was measured against $\beta$-glycerophosphate, ATP, and glucose-1-phosphate. Amylase and invertase were assayed using 1-percent solutions of soluble potato starch and sucrose, respectively. Tyrosinase (polyphenoloxidase) and peroxidase were also measured. Phosphatase procedures were described previously (1) as were those for invertase (2), amylase (3), tyrosinase (9), and peroxidase (8). Enzyme action was computed in terms of specific activity (units/milligram of protein). Protein was measured by the technique of Sutherland et al. (19).

Total ketose was measured by the resorcinol technique of Roe (17), and sucrose by the modification of Cardini et al. (10). Fructose was estimated by subtracting sucrose values from those of total ketose.

\section{RESULTS AND DISCUSSION}

\section{EFFECTS OF SI, FE, AND CN AS NUTRIENT SUPPLEMENTS}

The only plants showing visual effects of the nutrient-solution supplements were those receiving 200 p.p.m. of CN. These exhibited extreme stunting plus excessive yellowing and drying of older leaves. This condition was reflected by low total ketose and sucrose values in both leaf and meristem tissues (table 1). Fructose was increased in leaves by the high CN treatment. The low, or 20-p.p.m. CN treatment had no apparent effect on the young cane.

Both leaf and meristem enzymes appeared to be quite sensitive to the feeding-solution additives. Tyrosinase was 3 times more active in the stunted plants receiving high $\mathrm{CN}$ (table 2 , item 7 ). It is interesting that tyrosinase should behave thus in the affected canes, for other workers with other plants have reported abnormally high oxidase activity among, or adjacent to infected tissues $(13,16)$. Increased phenol content is even more widely recognized among infected plants $(11,12,14,15)$, presumably as a function of general disease resistance. This might reflect a decrease in oxidase activity or synthesis. Tyrosinase action was suppressed in cane 
TABLE 1.-Mean values for leaf and meristem sugars of immature sugarcane supplied with variable silicon, iron, and cyanide in sand culture ${ }^{1}$

\begin{tabular}{|c|c|c|c|c|c|c|c|}
\hline \multirow{2}{*}{ Item No. } & \multirow{2}{*}{$\begin{array}{c}\text { Treatment } \\
\text { (p.p.m.) }\end{array}$} & \multicolumn{3}{|c|}{ Leaf sugars- } & \multicolumn{3}{|c|}{ Meristem sugars- } \\
\hline & & $\begin{array}{r}\text { Total } \\
\text { ketose }\end{array}$ & Sucrose & Fructose & $\begin{array}{c}\text { Total } \\
\text { ketose }\end{array}$ & Sucrose & Fructose \\
\hline 1 & Control & 95.8 & 90.1 & 5.7 & 347 & 175 & 174 \\
\hline 2 & $\mathrm{Si}, 20$ & 98.2 & 94.4 & 3.8 & 323 & 162 & 161 \\
\hline 3 & Si, 200 & 100.5 & 98.1 & 2.7 & 356 & 200 & 156 \\
\hline 4 & $\mathrm{Fe}, 10$ & 98.2 & 94.3 & 4.1 & 330 & 169 & 161 \\
\hline 5 & $\mathrm{Fe}, 100$ & 97.1 & 93.6 & 3.6 & 351 & 182 & 168 \\
\hline 6 & $\mathrm{CN}, 20$ & 101.2 & 99.4 & 2.0 & 349 & 203 & 147 \\
\hline 7 & $\mathrm{CN}, 200$ & 62.6 & 49.4 & 13.2 & 241 & 145 & 96 \\
\hline Mean & & 93.4 & 88.5 & 5.0 & 328 & 177 & 152 \\
\hline
\end{tabular}

${ }^{1}$ Figures indicate milligrams per gram of dry weight.

TABLE 2.-Mean specific-activity values for leaf and meristem enzymes of immature sugarcane supplied with variable silicon, iron, and cyanide in sand culture

\begin{tabular}{|c|c|c|c|c|c|c|c|c|}
\hline Item No. & $\begin{array}{c}\text { Treatment } \\
\text { (p.p.m.) }\end{array}$ & $\beta$-GP-ase & ATP-ase & G-1-P ase & $\begin{array}{l}\beta \text {-Am- } \\
\text { ylase }\end{array}$ & $\begin{array}{l}\text { Perox- } \\
\text { idase }\end{array}$ & $\begin{array}{l}\text { Tyro- } \\
\text { sinase }\end{array}$ & Grand mean \\
\hline
\end{tabular}

Values for leaf enzymes

\begin{tabular}{l|l|r|r|r|r|r|r|r}
\hline 1 & Control & 29.0 & 35.6 & 12.0 & 289 & 73.7 & 15.5 & 75.8 \\
2 & $\mathrm{Si}, 20$ & 29.7 & 35.6 & 13.0 & 392 & 79.1 & 15.0 & 94.1 \\
3 & $\mathrm{Si}, 200$ & 23.4 & 27.5 & 10.3 & 311 & 75.2 & 9.8 & 76.2 \\
4 & $\mathrm{Fe}, 10$ & 23.8 & 26.3 & 8.8 & 247 & 63.1 & 12.2 & 63.5 \\
5 & $\mathrm{Fe}, 100$ & 23.7 & 27.5 & 11.4 & 256 & 91.5 & 22.4 & 72.1 \\
6 & $\mathrm{CN}, 20$ & 19.0 & 20.6 & 9.0 & 185 & 66.3 & 11.5 & 51.9 \\
7 & $\mathrm{CN}, 200$ & 30.1 & 31.6 & 12.7 & 237 & 62.0 & 50.2 & 70.6 \\
\cline { 2 - 7 } Mean & & 25.5 & 29.2 & 11.0 & 274 & 72.9 & 19.5 & 72.0 \\
\hline
\end{tabular}

Values for meristem enzymes

\begin{tabular}{|c|c|c|c|c|c|c|c|c|c|}
\hline & & & & & & & & $\begin{array}{c}\text { Inver- } \\
\text { tase }\end{array}$ & $\begin{array}{l}\text { Grand } \\
\text { mean }\end{array}$ \\
\hline 8 & Control & 17.8 & 18.3 & 7.6 & 382 & 135 & 51.3 & 3.3 & 87.9 \\
\hline 9 & $\mathrm{Si}, 20$ & 16.1 & 16.2 & 7.4 & 353 & 159 & 43.1 & 2.6 & 85.3 \\
\hline 10 & Si, 200 & 16.0 & 16.0 & 7.1 & 372 & 77 & 35.3 & 1.6 & 75.0 \\
\hline 11 & $\mathrm{Fe}, 10$ & 13.7 & 12.7 & 5.1 & 303 & 97 & 36.6 & 1.9 & 67.1 \\
\hline 12 & $\mathrm{Fe}, 100$ & 17.2 & 16.2 & 6.3 & 339 & 110 & 58.5 & 2.7 & 78.5 \\
\hline 13 & $\mathrm{CN}, 20$ & 18.5 & 16.5 & 6.6 & 336 & 87 & 46.6 & 2.2 & 73.3 \\
\hline 14 & $\mathrm{CN}, 200$ & 26.4 & 23.9 & 7.8 & 387 & 125 & 35.1 & 2.8 & 86.9 \\
\hline Mean & & 17.9 & 17.1 & 6.8 & 353 & 113 & 43.8 & 2.4 & 79.1 \\
\hline
\end{tabular}


meristem by the high $\mathrm{CN}$ treatment (table 2, item 14). Perhaps abnormal oxidase activity is a characteristic of all plants under stress.

High Si (200 p.p.m.) suppressed tyrosinase activity in leaves, while both the 20- and 200-p.p.m. treatments lowered tyrosinase activity in meristem (table 2 , items 3,9 , and 10). Invertase was far less active when either high or low Si levels were supplied. Both the tyrosinase and invertase inhibition by Si conform to earlier observations (18), and significance of this Si function is discussed in the earlier paper.

Iron at the rate of 10 p.p.m. suppressed each enzyme measured in both leaf and meristem samples (table 2, items 4 and 11). Meristem peroxidase and invertase were particularly affected, even though $\mathrm{Fe}$ is an essential component of the peroxidase system. We feel that the Fe effects are indirect, most likely dependent upon availability or content of other elements in the plant tissues. Earlier studies showed that invertase was suppressed by 6 p.p.m. of Fe supplied in sand culture, but only when molybdenum and calcium were in low supply (5). The same quantity of Fe stimulated invertase when molybdenum was high (1 p.p.m.).

\section{EFFECTS OF FOLIAR ADDITIVES}

Application of ascorbic acid, cysteine, and hydroxylamine to cane foliage had no appreciable effect on leaf and meristem sugar content. The high CN treatment (1,000 p.p.m.) caused increased sucrose in both tissues (table 3, item 12). None of the additives induced visible changes in the treated plants.

Each of the leaf enzymes assayed was somewhat suppressed by the high $\mathrm{CN}$ treatment (table 4, item 12). Again we feel that this is an indirect response. Only amylase and tyrosinase was severely affected by $\mathrm{CN}$. Cysteine at both the 50- and 1,000-p.p.m. levels caused marked increases in leaf amylase activity (table 4 , items 5 and 6 ). Although hydroxylamine and ascorbic acid are excellent oxidase inhibitors in vitro $(8,9)$, neither peroxidase nor tyrosinase were appreciably affected by the foliar treatments. Ascorbic acid was probably oxidized ${ }^{4}$ or metabolized, but the fate of hydroxylamine is totally obscure.

Meristem amylase and invertase were severely inhibited by the 1,000p.p.m. CN treatment (table 5, item 12). This invertase suppression may account for the high meristem sucrose values associated with 1,000 p.p.m. CN (table 3, item 12).

All of the meristem enzymes assayed revealed some degree of activation by the 50-p.p.m. cysteine treatment (table 5, item 5). Only tyrosinase was previously known to be affected by cysteine and this only as strong in vitro

${ }^{4}$ Unpublished experiments in Puerto Rico have revealed ascorbic acid oxidase in cane-leaf preparations. 
inhibition. The 1,000-p.p.m. cysteine application did, in fact, cause a slight suppression of tyrosinase, yet so great a concentration should not have been required. Furthermore, each of the other catalysts stimulated by low cysteine was also retarded by the high cysteine treatment.

TABLE 3.-Mean values for leaf and meristem sugars of immature sugarcane treated by foliar application of ascorbic acid, cysteine, hydroxylamine, and cyanide ${ }^{1}$

\begin{tabular}{|c|c|c|c|c|c|c|c|}
\hline \multirow{2}{*}{ Item No. } & \multirow{2}{*}{ Treatment (p.p.m.) } & \multicolumn{3}{|c|}{ Values for leaf sugars } & \multicolumn{3}{|c|}{ Values for meristem sugars } \\
\hline & & $\begin{array}{c}\text { Total } \\
\text { ketose }\end{array}$ & Sucrose & Fructose & $\begin{array}{l}\text { Total } \\
\text { ketose }\end{array}$ & Sucrose & Fructose \\
\hline 1 & $\begin{array}{l}\text { Ascorbic acid } \\
\text { Control }\end{array}$ & 95.3 & 85.1 & 103 & 311 & 428 & \\
\hline 2 & 50 & 99.5 & 90.7 & 8.9 & 309 & 58.2 & 251 \\
\hline 3 & 1,000 & 98.7 & 91.8 & 6.9 & 307 & 45.5 & 261 \\
\hline & Cysteine & & & & & & \\
\hline 4 & Control & 95.8 & 92.6 & 3.3 & 299 & 39.9 & 259 \\
\hline 5 & 50 & 95.3 & 91.1 & 4.2 & 291 & 29.6 & 262 \\
\hline 6 & $\begin{array}{l}1,000 \\
\text { Hydroxylamine }\end{array}$ & 95.2 & 89.8 & 5.4 & 287 & 26.4 & 261 \\
\hline 7 & Control & 93.7 & 85.4 & 8.3 & 269 & 39.3 & 230 \\
\hline 8 & 50 & 92.6 & 80.5 & 12.1 & 241 & 37.8 & 203 \\
\hline 9 & $\begin{array}{c}1,000 \\
\text { Cyanide }\end{array}$ & 84.9 & 72.5 & 12.4 & 251 & 32.1 & 219 \\
\hline 10 & Control & 90.4 & 64.0 & 26.5 & 300 & 54.6 & 245 \\
\hline 11 & 50 & 99.9 & 76.8 & 23.1 & 267 & 39.9 & 227 \\
\hline 12 & 1,000 & 101.1 & 89.5 & 11.6 & 312 & 93.3 & 219 \\
\hline Mean & & 95.2 & 84.2 & 11.1 & 287 & 45.0 & 242 \\
\hline
\end{tabular}

1 Figures represent milligrams per gram of dry weight. Each figure represents the computed mean of 4 replicates.

\section{SIGNIFICANCE OF ENZYME REGULATION IN SUGARCANE}

The experiments presented above constitute our latest effort toward enzyme regulation in sugarcane. While it is believed that many desirable changes can be induced in cane by control of critical enzymes, these studies have been only partly successful.

Certain chemicals have been shown to cause major enzyme changes in cane tissues, but with few exceptions these could not have been anticipated from in vitro findings, and the enzyme changes have not usually produced desirable results. Only the phosphatase inhibitors, molybdenum and tungsten $(4,6)$, and to a limited extent the amylase inhibitor, mercury $(7)$, have induced predictable results when supplied to living plants. We feel that the principle of enzyme control is sound, but few useful applications 
will be found until biologists have more thoroughly bridged the void between test-tube reactions and those of living organisms.

\section{SUMMARY}

Immature sugarcane was treated with chemical additives to determine whether significant and predictable changes could be induced in enzyme

TABLE 4.-Mean specific-activity values for leaf enzymes of immature sugarcane treated by foliar application of ascorbic acid, cysteine, hydroxylamine, and cyanide ${ }^{1}$

\begin{tabular}{|c|c|c|c|c|c|c|c|c|}
\hline \multirow{2}{*}{ Item No. } & \multirow{2}{*}{ Treatment (p.p.m.) } & \multicolumn{6}{|c|}{ Values for leaf enzymes- } & \multirow[b]{2}{*}{ Grand mean } \\
\hline & & $\beta$-GP-ase & ATP-ase & G-1-P ase & $\begin{array}{c}\text { Am- } \\
\text { ylase }\end{array}$ & $\begin{array}{l}\text { Perox- } \\
\text { idase }\end{array}$ & $\begin{array}{l}\text { Tyro- } \\
\text { sinase }\end{array}$ & \\
\hline 1 & $\begin{array}{l}\text { Ascorbic acid } \\
\text { Control }\end{array}$ & 29.8 & 32.1 & 13.4 & 151 & 320 & 8.1 & 92.4 \\
\hline 2 & 50 & 24.8 & 26.8 & 12.9 & 162 & 306 & 6.8 & 89.9 \\
\hline 3 & $\begin{array}{c}1,000 \\
\text { Cysteine }\end{array}$ & 25.7 & 27.7 & 12.5 & 146 & 304 & 7.2 & 87.2 \\
\hline 4 & Control & 26.6 & 28.8 & 11.8 & 140 & 375 & 10.1 & 98.7 \\
\hline 5 & 50 & 30.5 & 32.4 & 12.1 & 199 & 359 & 10.1 & 107.2 \\
\hline 6 & $\begin{array}{l}1,000 \\
\text { Hydroxylamine }\end{array}$ & 29.2 & 30.6 & 11.4 & 226 & 405 & 7.0 & 118.2 \\
\hline 7 & Control & 26.4 & 31.1 & 11.0 & 219 & 288 & 12.4 & 98.0 \\
\hline 8 & 50 & 25.5 & 31.0 & 12.1 & 173 & 281 & 5.5 & 88.0 \\
\hline 9 & $\begin{array}{c}1,000 \\
\text { Cyanide }\end{array}$ & 27.5 & 33.1 & 11.1 & 243 & 311 & 9.3 & 105.8 \\
\hline 10 & Control & 37.1 & 43.1 & 11.8 & 209 & 78 & 6.9 & 64.3 \\
\hline 11 & 50 & 34.6 & 39.0 & 11.3 & 191 & 76 & 4.9 & 59.5 \\
\hline 12 & 1,000 & 30.7 & 35.1 & 9.5 & 143 & 62 & 3.2 & 47.3 \\
\hline Mean & & 29.0 & 32.6 & 11.7 & 200 & 264 & 7.6 & 89.0 \\
\hline
\end{tabular}

${ }^{1}$ Each figure represents the computed mean of 4 replicates.

behavior. All plants were grown in sand culture with controlled nutrient supply.

One group received foliar application of ascorbic acid, cysteine, hydroxylamine and cyanide; the other group received silicon, iron, and cyanide as nutrient-solution supplements. Enzymes assayed included acid phosphatases, invertase, amylase, peroxidase, and tyrosinase (polyphenoloxidase). Each of the chemicals tested was known to affect one or more enzymes in vitro.

Plants receiving 1,000 p.p.m. of cyanide as a foliar spray increased sucrose in leaves and meristem within 3 days. All enzymes measured were suppressed by CN. Amylase was markedly stimulated by 50 and 1,000 
p.p.m. of cysteine. All the enzymes assayed were moderately stimulated by 50 p.p.m. of cysteine, whereas 1,000 p.p.m. caused general suppression.

Plants receiving 200 p.p.m. of cyanide as a nutrient-solution supplement were greatly stunted and revealed low sugar content of leaf and meristem tissues. Tyrosinase was about 3 times more active in high-cyanide plants than in controls.

\begin{tabular}{l} 
TABLE 5.-Mean specific-activity values for meristem enzymes of immature sugarcane \\
treated by foliar application of ascorbic acid, cysteine, hydroxylamine, and cyanide ${ }^{1}$ \\
\hline
\end{tabular}

${ }^{1}$ Each figure represents the computed mean of 4 replicates.

Silicon added to nutrient solutions at rates of 20 and 200 p.p.m. greatly retarded invertase and tyrosinase. This confirms similar observations recorded earlier, and it is suggested that enzyme inhibition is a physiological function of silicon in sugarcane. Iron added to nutrient solutions at the rate of 10 p.p.m. caused general enzyme suppression, particularly with regard to meristem peroxidase and invertase.

Significance of enzyme regulation in living cane is briefly discussed.

\section{RESUMEN}

Se trató caña de azúcar inmadura con aditivos químicos para determinar si es posible inducir cambios significativos que puedan predecirse respecto 
a la acción de las enzimas. Todas las plantas se sembraron en arena, controlándose el suministro de nutrimentos.

A un grupo se le hizo aplicaciones foliares de ácido ascórbico, cisteína, hidroxilamina y cianuro; al otro se le suministró silicio, hierro y cianuro en forma de una solución de nutrimentos suplementarios. Las enzimas que se probaron fueron las fosfatasas ácidas, invertasa, amilasa, peroxidasa y tirosinasa (polifenoloxidasa). Se sabía que cada uno de los agentes químicos probados afectaba una o más de las enzimas in vitro.

Las plantas que recibieron 1,000 p.p.m. de cianuro en forma de aspersión foliar aumentaron el contenido de sacarosa en las hojas y el meristemo en un espacio de 3 días. Todas las enzimas que se calcularon fueron inhibidas por el CN. La amilasa fue marcadamente estimulada por 50 a 1,000 p.p.m. de cisteína. Todas las enzimas que se analizaron fueron estimuladas moderadamente por 50 p.p.m. de cisteína, mientras que 1,000 p.p.m. causó un efecto inhibitorio general.

Las plantas que recibieron 200 p.p.m. de cianuro en forma de solución suplementaria de nutrimentos apenas crecieron, revelando un bajo contenido de sacarosa en los tejidos de las hojas y el meristemo. La tirosinasa fue 3 veces más activa en las plantas que recibieron grandes cantidades de cianuro que en las plantas testigo.

El silicio añadido a las soluciones de nutrimentos a razón de 20 y 200 p.p.m. retardaron grandemente la acción de la invertasa y la tirosinasa. Esto confirma observaciones previas, y sugiere que la inhibición enzimática es una función fisiológica del silicio en la caña de azúcar. El hierro añadido a las soluciones de nutrimentos a razón de 10 p.p.m. causó una inhibición enzimática general, especialmente en la peroxidasa y la invertasa del meristemo.

Se discute brevemente lo que significa la regulación enzimática en la caña de azúcar.

\section{LITERATURE CITED}

1. Alexander, A.G., Hydrolytic proteins of sugarcane: The acid phosphatases, J. Agr. Univ. P.R. 49(2): 204-28, 1965.

2. - Hydrolytic proteins of sugarcane: The acid invertases, J. Agr, Univ. P.R. $49(3): 287-307,1965$.

3. - Hydrolytic proteins of sugarcane: Amylase, J. Agr. Univ. P.R. 49(3): 30824,1965 .

4. - - Induction of varying sugar levels in leaves of immature sugarcane by use of acid phosphatase inhibitors, J. Agr. Univ. P.R. $49(1): 35-59,1965$.

5. - - Sucrose-enzyme relationships in immature sugarcane treated with variable molybdenum, calcium, iron, boron, lead, trichloroacetic acid, $\beta$-glycerophosphate, and starch, J. Agr. Univ. P. R. 49(4): 443-61, 1965.

6. - Effects of tungsten and molybdenum on sucrose content and hydrolytic enzymes of immature sugarcane, J. Agr. Univ. P. R. 49(4): 429-42, 1965. 
7. - Effects of amylase and invertase regulators upon sucrose content, protein content, and enzyme activity of immature sugarcane. J. Agr. Univ. P.R. 50(1): 18-35, 1966.

8. — - The oxidizing enzymes of sugarcane: Peroxidase, J. Agr. Univ. P. R. 50(1): 36-52, 1966.

9. - The oxidizing enzymes of sugarcane. Tyrosinase (polyphenol oxidase), J. Agr. Univ. P. R. 50(2): 113-30, 1966.

10. Cardini, C. E., Leloir, L. F., and Chiriboga, J., The biosynthesis of sucrose, J. Biol. Chem. 214: 149-55, 1955.

11. Cruickshank, I. A. M., and Perrin, D. R., Isolation of a phytoalexin from Pisum sativum L., Nature (London) 18\%: 799-800, 1960.

12. Davis, D., Waggoner, P. E., and Dimond, A. E., conjugated phenols in the fusarium wilt syndrome, Nature (London) 172: 959-61, 1953.

13. Farkas, G. L., Király, Z., and Solymosy, F., The biochemical mechanism of hypersensitive reaction in rust and virus infected plants, 9 th Int. Bot. Congr., Montreal 2: 111-7, 1959.

14. Király, Z., and Farkas, G. L., Relation between phenol metabolism and stem rust resitance in wheat, Phytopath. 52: 657-64, 1962.

15. Kúz, J., Henze, R. E., Ullstrup, A. J., and Quackenbush, F. W., Chlorogenic and caffeic acids as fungistatic agents produced by potatoes in response to inoculation with Helminthosporium carbonum, J. Amer. Chem. Soc. 78: 3123-25, 1956.

16. Maine, E. C., and, Kelman, A., Changes in the oxidation rates of polyphenols and ascorbic acid in tobacco stem tissue invaded by Pseudomonas solanacearum, Phytopath. 50: 645-53, 1960.

17. Roe, J. R., A colorimetric method for the determination of fructose in blood and urine, J. Biol. Chem. 10\%: 15-22, 1934.

18. Samuels, G., and Alexander, A. G., Effects of variable silicon and manganese on the nutrition and enzyme activity of sugarcane grown in sand culture, Plant Physiol. (in press) 1966.

19. Sutherland, E. W., Cori, C. F., Haynes, R., and Olsen, N. S., Purification of the hyperglycemic-glycogenolytic factor from insulin and from gastric mucosa, $J$. Biol. Chem. 180: 825-37, 1949. 